the readiness of the organism at all stages of educational process, the correctness of the chosen direction of training, the level and the dynamics of the training.

The basic methods of pedagogical control comprise pedagogical observations and control standards (tests). Control checks of the level of motor readiness must be carried twice a year and the results must be recorded in the registry book.

Medical methods of control are directed at defining the health state, level of physical development, physiological age and level of functional readiness of the organism. During training students-sportsmen progress, current or operative kinds of control are used.

Progress control attempts to show the change in the state of training of the studentssportsmen during the long period of training and to compare the initial indices of motor, technical and functional readiness with the same at the end of the year.

Current control characterizes the training effect of separate classes and monitors functional changes of the organism and its response to typical load (heart rate in every 7-10 days).

Operative control shows the effectiveness of one training class by the indices of heart rate, by physical signs (the color of the skin, respiratory rhythm etc.), by subjective feelings (well-being, desire to train, sustain of trainings, activeness at classes, mood).

Key words: students, students-sportsmen, methods of control, physical exercises, motor qualities.

УДК 37.013 .2

Сергій Корольов

Льотна академія Національного авіаційного університету

ORCID ID 0000-0003-0206-6794

DOI 10.24139/2312-5993/2019.05/104-120

\title{
ЗАРОДЖЕННЯ ТА ЕВОЛЮЦІЯ ПОНЯТЬ МЕХАНІКИ У СВІТЛІ ПОКРАЩЕННЯ МЕТОДИКИ Ї̈ ВИКЛАДАННЯ
}

Пропонується цикл нових комплексних підходів до покращення методики викладання механіки. Раніше запропоновані методи вдосконалення методики ще знаходяться в ужитку, але їх потенціал виявився майже вичерпаним у даний час. Має багатообіцяючі перспективи даний комплексний підхід, який базується на комплексному застосуванні масиву з декількох базових засад, які креативно та нестандартно комбінуються між собою в багатьох варіантах, у залежності від конкретної ситуації. До мінімального масиву засад входять такі, як: використання досвіду з історичної еволюції базових понять механіки; основні поняття з теорії інформації; застосування комп'ютерної техніки та навчальних програмних продуктів; створення великої множини математичних моделей; комбінаторне поєднання базових засад із метою одночасного використання декількох засобів для вирішення конкретної проблеми. Їх комплексне застосування повинне дати мультиплікативний ефект.

Ключові слова: еволюція, механіка, математична модель явища, теорія інформації, діалектична взаємодія, комбінаторне поєднання, мультиплікативний ерект. 
Постановка проблеми. Наш час характеризується значним зростанням вимог до рівня кваліфікації випускників закладів вищої освіти як з боку суспільства, так і роботодавців. Проблема поглиблюється досить невисоким рівнем шкільної підготовки студентів. Значну роль в одержанні кваліфікаційних знань та вмінь у випускників відіграє вивчення технічної механіки, особливо це актуально для авіаційних закладів як розробників та носіїв передових технологій у цивілізованому світі. На це впливає низка важливих факторів:

1) глобалізація світової економіки, що впливає на виробництво матеріальних цінностей в усіх країнах, у тому числі в Україні;

2) конкуренція за робочі місця з випускниками кращих закладів освіти світу;

3) невпинний розвиток нових технологій, що потребує значної кількості кваліфікованих спеціалістів, які готові сприйняти та створити технологічні новації;

4) необхідність компенсувати невисокий рівень шкільної підготовки.

Аналіз останніх досліджень і публікацій. Автору статті невідомі більш ранні публікації, які розглядають навчальний процес по вивченню механіки як єдиний діалектичний комплекс з таких пов'язаних між собою складових:

1) теорія інформації;

2) комп'ютерні технологій;

3) метод математичних моделей;

4) стандартна методика викладання механіки;

5) урахування історичного розвитку базових понять механіки.

На думку автора, поєднання цих підходів повинне дати мультиплікативний ефект, тобто загальний ефект буде значно більшим, ніж просто арифметична сума складових.

Звичайно, що над покращенням методики викладання працювало багато спеціалістів.

А. Границька (Границкая, 1991) запропонувала створити адаптивну систему навчання, у якій треба дорогоцінний час уроку ділити поміж різними учнями в залежності від їх здібностей.

В. Д'яченко (Дьяченко, 1989) створив та впровадив у дію систему керування структурою навчального процесу в залежності від конкретної ситуації.

Н. Тализіна (Талызина, 1975) запропонувала гнучко керувати вчителем процесом засвоювання знань учнями в залежності від здібностей учнів. 
І. Е. Унт створила систему диференціації навчання в залежності від здібностей учнів, у якій основна частка роботи припадає на індивідуальну роботу з учнями.

В. Д. Шадріков висунув ідею класів змінного складу учнів по кожній навчальній дисципліні, що приведе до конкуренції між учителями за учнів.

Мета статті - привернути увагу педагогів до нових можливостей, які виникають у викладанні механіки внаслідок використання діалектичного підходу, коли в органічній єдності співпрацюють та підсилюють один одного теорія інформації, комп'ютерні технології, метод математичних моделей та аналіз історичного розвитку базових понять механіки.

Методи дослідження. Застосовується метод послідовних наближень та метод порівняльного аналізу, при яких одержані результати поступово ускладнюються та наближаються до реальності. Використовується метод запозичення понять із інших наук, що дозволяє застосовувати більш розроблені розділи інших наук у менш опрацьованих розділах науки.

Виклад основного матеріалу дослідження. Філософ давньої Греції Геракліт із Ефесу стверджував: «Не можна вступити двічі в один і той самий потік і до суті смерті ніхто не може доторкнутися двічі». Цей вислів у наш час більше відомий у варіанті: «Все тече, все змінюється» (Гераклить Ефесскій, 1910). Він також говорив, що «Цей космос, однаковий для всіх, ніхто з богів чи людей не створив, космос був вічно, і $\epsilon$, і буде вогнем вічно живим, який регулярно горить та погасає».

Ці твердження можна віднести до багатьох напрямів діяльності людини. Думку філософа можна розуміти по-різному, цілком можлива така точка зору, що уявлення людства про оточуючий світ постійно змінюються, стають повнішими знання про закони розвитку світу, а також стають більш ефективними засоби вивчення реальності та вдосконалюються методи передачі знань наступним поколінням.

На переконання автора, важливим $€$ факт передачі знань та корисної інформації від покоління до наступного покоління людей. Кваліфіковане передавання знань та вмінь учням - сутність педагогіки. Саме це сприяє розвиткові цивілізації та робить із просто людини Homo sapiens. Процес накопичення та трансляції знань повинен бути максимально ефективним для успіху конкретної цивілізації. Учений Платон свого часу стверджував, що голова людини - це не пустий горщик, який треба чимось наповнити, а факел, який треба запалити (Платон, 1899). Ефективне «горіння факелу» треба доповнювати знаннями та педагогічною практикою. Філософ Давньої 
Греції Протагор був упевнений, що людина являє собою міру всіх речей, тобто які люди, то таке й суспільство.

Фантастична складність навколишнього світу багато сотень років притягує до себе увагу допитливих людей. Академік Я.Б. Зельдович стверджував, що «духовні потреби людини ніколи не обмежувалися сприйняттям мистецтва, музики, краси природи. Знання та розуміння будови природи також $€$ однією з потреб людини». Фундаментальна наука $\epsilon$ чудовим зразком творчості людського розуму. Взаємні відносини між навколишнім світом і людством є складними, форми цих відносин багатогранні й не $є$ до кінця дослідженими. Важливу роль у дослідженні світу грає наука, яку можна визначити як систематичне зібрання теоретичних законів і методів експериментального дослідження сукупності предметів (Готт, 1988).

Тривалий час у первісних людей елементи науки була тісно переплетені з релігією, забобонами, мистецтвом. 3 часом у деяких народів об’єм знань досягав певної критичної межі, відповідно до законів діалектики кількість переходила в якість, наукові факти узагальнювалися та відокремлювалися від релігії та мистецтва, сама наука продовжувала розвиватися та ускладнюватися із накопиченням нової інформації.

Важливою науковою дисципліною $€$ механіка, яка виникла кілька тисяч років тому, весь цей час вона безперервно розвивалася і сприяла розвиткові цивілізації всього людства. Тривалий час механіка була одним цілим із математикою, астрономією, природознавством, якщо використовувати сучасні терміни.

Одна з перших теорій світобудови ґрунтувалася на тому, що Земля знаходиться на спинах трьох китів, які пливуть у нескінченному океані.

Число «три» тут має вирішальне значення - саме при такому співвідношенні між числом ступенів свободи і числом матеріальних точок забезпечується максимальна жорсткість конструкції при відомій геометрії сучасного нам простору-часу. Не випадковим $є$ той факт, що мільйони будівельних арок являють собою сукупність десятків або сотень трикутників, з'єднаних разом складним чином, таку оптимальну конструкцію пропонує розділ технічної механіки.

Число «три» знаходиться між двома фундаментальними ірраціональними константами: одна з них - це основа натуральних логарифмів, друга - це відношення довжини кола до його діаметру. У цьому факті проявляється одне з базисних понять науки.

Перші знання з механіки з'явилися в стародавньому Єгипті, але до нас ці знання майже не дійшли. Інші народи створювали свої системи 
знань, але найдавніші письмові документи про механіку збереглися у стародавніх греків. Тому простежити за появою та розвитком перших понять механіки можна на прикладі стародавньої Греції (История механики, 1972; Веселовский, 1974).

Термін «механіка» позначав колись підйомну машину в давньогрецькому театрі, що піднімала та опускала акторів, які грали ролі богів у виставах того часу (Веселовский, 1974). Це дало життя вислову «Бог з машини».

Розділи науки до початку XVI століття були одним цілим та мали назву «натурфілософія». Зокрема, оптика, як наука, теж зародилася в давньогрецькому театрі як реакція на потребу в створенні декорацій театру з урахуванням вимог перспективи.

Потім словом «машина» стали називати військові пристосування i спеціальні знаряддя для взяття міст під час війни.

Одним із перших творців механіки був Аристотель. Він залишив кілька праць з механіки - «Метафізика», «Механічні проблеми» та інші. Аристотель говорив, що «здивування - це початок знань». (Аристотель, 1975).

Учений під рухом (у наш час це розділ механіки «Кінематика») розумів зміни взагалі, кількісні та якісні зміни, а також зміни щодо місця положенні чого-небудь. Він рухом називав також перехід із буття в небуття, зі здорового стану людини в хворобу та навпаки. Такі уявлення суттєво відрізняються від сучасного розуміння поняття руху.

Для мислителя вже в ті часи важливо було вказати початкову й кінцеву точку руху, тобто він фактично використовував вектори (впорядковану пару чисел) для позначення руху. У закінченому вигляді векторна теорія з'явилася через сотні років потому. Застосування векторів, тобто спрямованих відрізків, призводило до проблем у спробі наукового опису обертального руху. Таким чином, використовуючи вектори в тогочасному розумінні, було складно описати обертальний рух.

Аристотель круговий рух розглядав як переміщення предмета 3 одної точки простору знову до неї (Аристотель, 1975).

Він уперше у світі ввів у розгляд поняття сили, яка виконує насильницькі дії, цю силу він назвав «Дінаміс». Сучасна механіка має важливий розділ, названий «Динаміка», який вивчає рух тіл під дією сил. 3 нього відомо, що сила дорівнює добутку маси тіла на прискорення, з яким це тіло рухається (це 2-й закон Ньютона).

Мислитель отримав вираз, у якому сила дорівнює добутку маси тіла на його швидкість. У сучасній механіці на це $є$ інша точка зору, добуток маси тіла на його швидкість називається імпульсом. 
Аристотель у своїх працях не використовував такі поняття, як тіло відліку і система координат, кажучи сучасною мовою. Ймовірно, він навіть не здогадувався про існування таких понять.

Аристотель, з точки зору аналізу розвитку механіки, запропонував для широкого вживання іншими користувачами такі поняття:

1) маса;

2) швидкість:

3) сила;

4) рух по прямій лінії;

5) обертальний рух;

6) помилково думав, що рух тіла є до тих пір, поки діє сила;

7) спробував зв'язати між собою силу, масу та швидкість тіла, вважав, що швидкість падіння пропорційна вазі тіла, це не так.

Для класифікації видів руху давні греки ділили весь світ на підмісячний і надмісячний. Надмісячний світ був, на їхню думку, вічним, досконалим і незмінним. Підмісячний світ був схильний до змін, у ньому все кипіло й вирувало, з'являлося і зникало.

Тому види руху греки ділили на природні і примусові. Природні види руху відбувалися самі по собі, без втручання сторонніх сил (у наш час такий рух називають інерційним рухом). Примусовий рух вимагає для себе наявності зовнішньої причини (або сили в нинішньому розумінні).

Греки розглядали природний рух як прагнення тіла зайняти своє природне певне місце. Для важких тіл природним місцем перебування була Земля - вважали греки. Тому камінь сам по собі падав на Землю, це був його природний рух. Для того, щоб камінь рухався вгору, необхідно було докласти якусь зовнішню силу, такий рух греки називали примусовим. Як видно, це була одна з перших в світі спроб описати сили гравітації.

Якщо греки хотіли розглянути вогонь, то для нього природним рухом був рух угору, а для руху вогню вниз необхідно було прикласти зовнішній вплив.

Природне прагнення греки позначили терміном «ропе», що українською мовою перекладається словом «рухатися». Оскільки в підмісячному світі все $\epsilon$ короткочасним і минущим, то рух повинен мати свій початок і свій кінець, а сам рух має здійснюватися по відрізках прямої лінії. У надмісячному світі все $€$ вічним, незмінним та ідеальним, отже, природний рух там має бути вічним, рівномірним і круговим. Рух по колу, на думку греків, має божествений характер. 
Термін «ропе» в чомусь близький до сучасного поняття «інерція», але за сучасними поняттями рух за інерцією може бути лише прямолінійним і рівномірним, це стверджує I закон Ньютона. При зустрічі з перешкодою рух за інерцією припиниться.

Стародавні греки вважали, що «ропе» буде проявляти себе при зустрічі з перешкодою таким чином - як тільки одна 3 точок тіла зустрінеться 3 перешкодою, то інерція інших точок змусить їх продовжувати рух. Отже, тіло далі буде обертатися навколо нерухомої точки, а інерція призведе до виникнення обертального моменту, на їх думку. Можлива ситуація, вважали стародавні греки, коли інерція одних точок тіла буде компенсувати інерцію інших, тоді тіло зупиниться. Такий стан тіла греки називали рівномоментність, у перекладі сучасною мовою.

Сучасна механіка такий стан називає рівновагою, закріплену точку звичайно називають центром тяжіння. Греки цю точку називали центром моментів, що не збігається з сучасними уявленнями. Викликає повагу той факт, що греки змогли створити струнку і без внутрішніх протиріч систему знань із механіки.

Наступним кроком було визначення інерції чисельно. Сучасний підхід під процесом вимірювань розуміє зіставлення вимірюваної величини 3 деяким еталоном, який прийнятий за одиницю. Архімед використовував інший підхід - пропорційності двох значень однієї і тієї самої величини. Фактично мислитель використовував правило рівності моментів сил добуток першої сили на її плече дорівнює добутку другої сили на її плече, але це сучасне трактування цього правила механіки. Учений таким чином вимірював момент сили, у сучасних термінах. Також ним було відкрито закон, який увійшов в історію під його іменем. Для підтвердження тези, що в той час всі види сучасної науки були одним цілим, необхідно сказати, що Архімед також визначив відношення довжини кола до його діаметру як 22/7 і фактично ввів у вживання поняття паралакса.

Учений уперше розглянув питання визначення центру ваги різних фігур. Це було важливо при розробці нових видів машин. Разом із тим треба відзначити, що за часів мислителя поняття «швидкість» окремо не існувало, у той час було прийнято говорити «більш швидкий, менш швидкий» (История механики, 1972; Веселовский, 1974).

Архімед зробив такий внесок у розвиток механіки:

1) увів поняття моменту сили;

2) використав рівність моментів двох сил;

3) розглядав умови рівноваги тіла; 
4) запропонував метод вимірюванню маси тіла;

5) увів поняття «центр ваги».

Учений Герон Олександрійський також зробив вагомий внесок у розвиток механіки. Він круговий рух визначав як рух двох половин одного колеса - одна частина колеса рухається зліва направо, інша половина колеса одночасно рухається справа наліво. Мислитель вивчав зв'язок між кутовою швидкістю тіла при його обертальному русі і лінійною швидкістю точок цього тіла при цьому обертанні.

у його час була вирішена математична задача про подвоєння куба, що потім допомогло в розробці нових видів машин. Він переглянув підхід до визначення поняття сили, оскільки ним було визнано непридатним те визначення сили, що запропонував Аристотель. При новому підході вважалося, що тіло, яке рухається, на початку руху отримує деяку рушійну силу, яка підтримує потім рух, коли ж рушійна сила вичерпується, то тіло зупиняється. У сучасних термінах ця «рушійна сила» називається «енергія». Подібний підхід потім застосовував Рене Декарт.

Герон зробив такий внесок в розвиток механіки:

1. Дав своє визначення кругового руху.

2. Запропонував поняття «рушійної сили».

3. Ввів поняття «енергія», по суті.

Ішов процес зародження й розвитку небесної механіки, яка була суттєвою складовою механіки в ті часи. Спочатку накопичувався матеріал спостережень, потім йшла пора узагальнень, потім мав місце розвиток теорій. Цей процес описується діалектикою, ії законами. У цей розвиток значний внесок зробили народи Близького Сходу. Саме там виникла система числення з базою 60. Тому дотепер , вже більше трьох тисяч років, весь світ використовує систему відліку часу, у якій 1 хвилина містить 60 секунд, 1 година містить 60 хвилин і так далі. Ясно, що без точного вимірювання часу неможливо виконати виміри ні швидкості, ні прискорення тіла, ні інших механічних характеристик. Спочатку вибір у якості бази числа 60 носив релігійно-містичний характер - по моделі Землі давні народи Вавілону та Шумеру вважали, що Сонце вдень по небесній півсфері ніс бог, який робив в дорозі 180 кроків, потім він робив 180 кроків під землею. Згодом була помічена властивість числа 60 - воно ділилося без залишку, націло, на 2, 3, 4, 5, 6, 10, 12, 15, 20 і 30. Як видно, це дає значно більше переваг, ніж використання сучасної десяткової системи, 3 базою 10. Десяткова система була введена за часів Великої французької 
революції, порівняно недавно в історичному плані. Єдиною перевагою десяткової системи є той факт, що в людини $€ 10$ пальців.

У сучасній техніці, яка базується на французьких стандартах, вважають за недолік множник 3, якщо число 3 входить або в числове значення відстані, або в числове значення інтервалу часу. Тому десяткова система не сприймає одиниці лінійних розмірів дюйм, фут, ярд та похідні від них одиниці площі та об'єму. Відомо, що 1 ярд містить 3 фути або 36 дюймів, 1 фут містить 12 дюймів. Англійська система мір базується фактично на Вавілонських засадах одиниць вимірів.

Ця система мір дозволяє вимірювати як простір у ярдах, футах, дюймах, так і час - у годинах, хвилинах, секундах, та також інші фізичні величини, наприклад, температуру. Відомо, що в температурній шкалі Фаренгейта інтервал між двома реперними точками поділено на 180 частин, що органічно поєднується 3 60-річною системою. У шкалі Цельсія інтервал між двома реперними точками поділено на 100 частин.

Понад три тисячі років весь цивілізований світ використовує 60-річну систему відліку часу, у тому числі і в механіці. Система виміру часу встояла, як не намагалися ії замінити. Це найбільш довгострокова система мір з усіх, які коли-небудь існували на Землі. Відносно вимірів точного часу треба додати, що в Англії до середини XX ст. у великих містах існувала служба по продажу точного часу - спеціальна людина з точним хронометром їздила за адресами і коригувала покази годинників клієнтів. Так тривало до створення служби передачі сигналів точного часу по мережі радіоприймачів.

3 геометрії відомо, що прямий кут дорівнює 90 градусів, кути вимірюються в 60-річній системі, що також органічно витікає з Вавілонської системи мір.

В Античні часи був відкритий закон збереження маси. Емпедокл вважав, що ніщо не може виникати з нічого і ніщо не може бути знищено. Практика змушувала зіставляти між собою різні предмети, тому були винайдені ваги. Це привело до виникнення еталонів ваги тих часів, як, наприклад, карат (История механики, 1972; Веселовский, 1974).

Тиск із боку десяткової системи мір привів до зникнення багатьох традиційних методів вимірювання маси, відстані, температури та інших еталонів фізичних величин, які не вписувалися в десяткову систему, наприклад: пуд, фунт, вершок, лінія, сажень тощо.

Кілька тисяч років тому була помічена прецесія точки весняного рівнодення по небу. У ті часи були складені списки затемнень Сонця і Місяця, що тоді трактувалося як гнів або милість давніх богів. По суті це були перші 
кроки в спробі відкрити закони небесної механіки і застосувати їх до опису явищ природи. У цей самий час починають відділятися один від одного релігія і наука, наука намагається знайти десь початок всіх початків - то в воді, як Фалес, то в повітрі, як Анаксимен, то у вогні, як Геракліт (История механики, 1972; Веселовский, 1974).

За часів стародавньої Греції природні процеси намагалися описати та аналізувати в математичній формі. Явище зміни фаз Місяця було вперше пояснено Анаксогором, у той же приблизно час у Вавілоні для пояснення фаз Місяця висунули теорію, що Місяць складається з двох половин - одна половина чорна, друга половина темна.

Першу кінематичну модель Сонячної системи на основі узагальнених міркувань та відомих на той час механічних законів побудував Евдокс Кнідський, який заперечував ідеальний характер кругового руху небесних світил. Свою кінематичну модель Сонячної системи Евдокс створив на основі системи складних сферичних рухів, на кожне небесне тіло було потрібно залучити дві, три або навіть більше сфер для пояснення всіх особливостей руху планет, Сонця і Місяця.

3 невеликими вдосконаленнями ця модель одержала назву модель Аристотеля, вона визнавалася коректною до робіт Коперника. Ця модель піддавалася критиці, оскільки в ній центром Всесвіту вважалася Земля, у реальності це не так, тому ще в ті часи було зрозуміло, що модель містить низку розходжень із результатами спостережень.

Для усунення цих суперечностей було запропоновано певні вдосконалення, найближчою до реальності була пропозиція від Тихо Браге. Треба відзначити сміливість Коперника для свого часу, він публічно заявив про те, що Сонце, а не Земля, знаходиться в центрі системи планет (Веселовский, 1974).

До цієї ідеї за багато століть до Коперника прийшов грек Аристарх, який вимірював кутові розміри Місяця, Сонця і орбіт світил. Аристарх дійшов висновку, що діаметр Сонця в 7 разів більше діаметру Землі, отже, обсяг Сонця в 343 разів більше обсягу Землі. Йому було ясно, що велике тіло не може обертатися навколо маленького, насправді все навпаки.

Але теорія Аристарха не отримала широкої підтримки свого часу. Ця теорія базувалася на тих засадах, що обертання планет навколо Сонця має здійснюватися по кругових орбітах і цей рух повинен бути рівномірним. У реальності, як ми знаємо, планети рухаються по еліптичних орбітах і швидкість руху планет змінюється від точки до точки. Деякі теорії та моделі світу стародавніх учених з висоти сучасних знань здаються далекими від істини. 
Але обґрунтована думка про закони природи завжди з великими труднощами долала перешкоди та знаходила розуміння у відомих учених того часу.

Аристотель, як відомо, у своїх працях не використовував такі поняття, як тіло відліку і система координат. Коперник вирішив вибрати тіла відліку, відносно яких треба розглядати рух Землі і Сонця. У якості тіл відліку він вибрав нерухомі зірки. Вдалий вибір точки відліку дозволив йому зробити правильний висновок і помістити Сонце в центр Сонячної системи. Таким підходом до вирішення складного завдання Коперник показав те, що правильний вибір системи координат значно спрощує вирішення складного завдання, чим користуються мільйони механіків з тих пір.

Заслуга вченого є також у стійкості відстоювання своєї позиції і наполегливість у широкій пропаганді своєї теорії. Його теорію далеко не всі прийняли і не всі вчені були з нею згодні, вона витримала перевірку жорсткою критикою.

Унесок Коперника в розвиток механіки був такий:

1. Запропонував використовувати поняття тіло відліку.

2. Використовував системи координат.

3. Пропагував у тогочасних ЗМІ, кажучи нашою мовою, свої наукові теорії.

Чергове надбання механіки сталося у Франції (История механики, 1972; Веселовский, 1974). Це було пов'язано з появою «готичного стилю» в архітектурі. Готичний стиль з'явився на півночі Франції, однією з ключових характеристик цього стилю є споруда великих соборів. Усередині собору часто збиралися жителі для вирішення гострих проблем, але таке призначення собору вимагало великих внутрішніх площ і великих лінійних розмірів споруди. А цей факт, у свою чергу, вимагав вирішення проблеми перекриття великих прольотів у ситуації, коли до відкриття і впровадження в практику будівництва виробів із залізобетону було багато сотень років.

На допомогу прийшла механіка, спираючись на досягнення минулих епох. Така річ, як похила площина, була відома ще стародавнім єгиптянам і широко застосовувалася при будівництві пірамід і храмів, але закони ії дії залишалися таємницею для механіків тисячі років. Головна проблема була в нерозумінні явищ тертя при русі одного тіла по поверхні іншого.

Стародавні механіки навіть не могли уявити, що під час руху одного тіла по поверхні іншого виникає сила, яку згодом назвали силою тертя. Виявилося, що простіше було придумати основи інтегрального числення, ніж усвідомити те, що факт тертя призводить до появи сили тертя. Природа 
тертя й зараз не до кінця зрозуміла. Навіть у сучасних підручниках 3 механіки про тертя говориться дуже схематично і спрощено.

Завдання про рівновагу тіла на похилій площині вирішив учений Неморарій (История механики, 1972; Веселовский, 1974). Він першим у світі усвідомив різницю між поняттям «вага тіла» і «маса тіла». Правда, в ті часи вагою називали величину, яку зараз позначають терміном «маса», а замість нинішнього поняття ваги використовували термін «тяжкість». Ця різниця двох тісно пов'язаних понять приводила до нерозуміння. Зрозуміло, що в цій ситуації важливу роль починає грати сила, що отримала в наш час назву реакція опори. Реакція опори істотно залежить від кута нахилу площини до лінії горизонту, а сила тертя залежить від реакції опори і від коефіцієнта тертя, який характеризує ступінь гладкості тіла і похилої площини.

Знання законів тертя дозволило механікам того часу розробити потрібні для практики перекриття, що призвело до появи характерних гострих шпилів. Лише з початком космічної ери відмінність між поняттями «вага» і «маса» змогли побачити мільйони людей.

Унесок Неморарія в розвиток механіки в цілому такий:

1. Розглянув похилу площину.

2. Знайшов умови рівноваги тіла на похилій площині.

3. Запропонував до вжитку поняття «сила тертя».

4. Указав на різницю між поняттями «маса» та «вага».

Рене Декарт зробив значний вклад у розвиток механіки. Декарт не вірив сліпо в авторитет знаменитостей і не вірив у містику, був проти схоластики, виступав за науковий шлях розвитку механіки та науки в цілому (Декарт, 1989).

Він піддав критичному аналізу отримані раніше іншими вченими результати та діийшов висновку про те, що сумніватися можна в будьякому твердженні, крім одного - «я мислю, отже, я існую».

На цьому твердженні, як на фундаменті, учений побудував свою систему поглядів. Підхід Декарта до отримання нових знань будувався на проведенні спочатку дослідів, а вже потім - на аналізі отриманих результатів, саме дослід у нього стояв на першому місці.

Мислитель запропонував у вжиток декартову систему координат, яка набула найширшого розповсюдження в математиці і в механіці. Без системи координат неможливе вирішення навіть найпростіших завдань з механіки. Він фактично створив аналітичну геометрію, що також допомогло у вирішенні 
завдань механіки. Віра в силу механіки в нього була настільки великою, що навіть живі істоти він розглядав як певні біологічні машини.

Декарт розробив свою теорію про еволюцію світу, він був проти ідеї створення світу відразу в «готовому вигляді» кимось або чимось. Це теж близько до сучасного погляду на світ як на постійно мінливу систему. Учений заперечував наявність порожнечі в природі, за його уявленнями весь світ був заповнений матерією, яка мала різні форми. Матерія між зірками та планетами знаходилася в постійному русі, ця матерія одержала назву «ефір».

Мислитель вважав головною формою руху матерії вихори різних масштабів в ефірі, саме вихори, на його думку, приводили в рух планети і Сонце, Сонячна система була залучена в більш масштабний вихор. Ця картина схожа на сучасний погляд на сонячну систему, на її обертання навколо центру Галактики, на рух нашої Галактики в місцевому скупчені галактик.

Картина створення світу в Декарта була універсальною, в її основі лежали три базові елементи матерії, які беруть участь у вихровому русі, кожен на своєму рівні.

Кажучи сучасною мовою, це схоже на рух електронів по своїх орбітах навколо ядра атома. Потім із вихрових рухів різного масштабу утворюються зірки та планети. Після цього вихровий рух приймає форму органічного життя, а це потім призводить до появи людини.

Від ідеї «суперсістоти» учений не відмовляється повністю, але її роль у теорії Декарта зводиться тільки до створення матерії, а далі все відбувається без її втручання, за рахунок вихорів різного масштабу. Це майже повністю збігається з сучасними поглядами на походження і розвиток Всесвіту, лише якщо «суперістоту» замінити на Великий Вибух.

Декарт запропонував свої закони інерції, перший - «всяке тіло залишається в тому стані, у якому воно знаходиться, поки інші причини його не змінять», а також другий - «матеріальне тіло, продовжуючи свій рух, буде рухатися по прямій лінії, ніколи не по кривій».

Декарт тяжіння тіл до Землі пояснював особливим вихором в ефірі. Вихор, який бушує навколо Землі та навколо інших планет і Сонця, унаслідок свого руху відкидає до центру всі тіла, що знаходяться на поверхні. Він був упевнений, що птахи, які зможуть злетіти високо над поверхнею Землі, зможуть вилетіти із зони дії вихору гравітації, а якщо вистрілити з потужної гармати вертикально вгору, то ядро гарантовано полетить у далекий космос.

Ідея Декарта про вихори ефіру не признавалася сотні років. Але з розвитком механіки в ії надрах зародилася і стала самостійною наукою 
квантова механіка. Стало ясно, що електрони - це не точкові згустки заряду, як вважалося, а в деяких випадках можна вважати, що електрони являють собою хмару заряду, яка крутиться навколо ядра атома. Це явище отримало назву "дуалізм», тобто кожна частинка мікросвіту являє собою як частку, так і хвилю. Тому ідея Декарта, на новому рівні розуміння, має право на життя.

Він досліджував явища, які мають місце при ударі двох матеріальних тіл, що згодом привело до появи такого поняття в механіці, як «імпульс». Учений указав, що імпульс тіла залежить від маси тіла та від його швидкості. Правда, мислитель вважав, що імпульс - величина скалярна, але сучасний погляд на імпульс полягає в тому, що імпульс - величина векторна і збігається за напрямком із напрямком вектора швидкості тіла.

Також мислитель вважав можливим розширити поняття імпульсу на всі тіла у Всесвіті і він вважав, що має місце закон збереження суми імпульсів всіх тіл. Це близько до сучасної точки зору на суму імпульсів системи тіл (Декарт, 1989).

Роботи Декарта, та інші фактори, спонукали Ньютона до міркувань та формулювання законів відносно істинної картини світобудови.

Внесок Декарта в розвиток механіки в цілому такий:

1. Запропонував ортогональну систему координат.

2. Дав сучасну математичну символіку та дослідив нові розділи математики, що застосовувалося також при розгляді проблем механіки.

3. Ввів поняття вихори «ефіру», яким заповнений Всесвіт.

4. Відкрив 2 закони інерції, які близькі по суті до сучасної точки зору.

5. Запропонував поняття «імпульс», але як скаляр, що є помилкою.

6. Ввів поняття «сума імпульсів» системи тіл.

Висновки. Історичний досвід розвитку механіки та інших наук показує, що оточуючий нас світ можна розглядати як велику «чорну скриньку», яку цивілізоване людство поступово досліджує. У процесі дослідження ми створюємо різні математичні моделі внутрішньої будови цієї скриньки, моделі спочатку прості, які потім ускладнюються. Ці моделі поступово наближуються до істинної будови світу, унаслідок поступового збільшення інформації в дослідників, яку вони згодом опрацьовують. Масив учених різних епох і різних народів можна розглядати як своєрідний аналоговий комп'ютер, у якому кожен дослідник являє собою по суті окремий процесор, всі ці біологічні процесори разом працюють над складним та масштабним спільним завданням. Логічно допустити, що при викладанні механіки буде корисно слідувати за історичною послідовністю 
розвитку понять та ідей, які виникали в процесі розвитку ідей та еволюції механіки. Є вагомі підстави вважати, що в процесі вивченні понять механіки студентами такий шлях забезпечить у цілому мінімум труднощів, тобто має місце мінімум затраченої на навчання енергії, якби це було не так, то тоді еволюція механіки в цілому пішла б іншим шляхом.

\section{ЛІТЕРАТУРА}

Аристотель (1975). Сочинения: в 4 т. М.: Мысль (Arystotel (1975). The Works: in 4 volumes. M.: Thought).

Боголюбов, А. Н., Штокало, И. З., Цыганкова, Э. Г. и др. (1987). История механики в России. Киев: Наукова Думка (Boholiubov, A. N., Shtokalo, I. Z., Tsyhankova, Е. Н. (1987). The History of Mechanics in Russia. Kiev: Scientific thought).

Веселовский, И. Н. (1974). Очерки по истории теоретической механики. М.: Высш. школа (Veselovskii, I. N. (1974). Essays on the History of Theoretical Mechanics. M.: Higher School).

Гераклить, Ефесскій. (1910). Фрагменты. М.: Мусагеть: Тип. Г. Лисснера и Д. Собко (Geraklit Efesskij. (1910). Abstracts. M. Musaget: Tip. G. Lissnera i D. Sobko).

Готт, В. С. (1988). Философские вопросы современной физики. М.: Высш. шк. (Gott, V. S. (1988). Philosophical Issues of Modern Physics. M.: Higher School).

Границкая, А. С. (1991). Научиться думать и действовать: Адаптивная система обучения в школе. М.: Просвещение (Granitskaia, A. S. (1991). Study How to Think and Act: Adaptational Training System in the Secondary School. Moscow).

Декарт, Рене (1989). Сочинения: в 2-х т. М.: Мысль (Dekart Rene. (1989). The Works. М.: Thought).

Дьяченко, В. К. (1989). Организационная структура учебного процесса и ее развитие. М.: Педагогика (Diachenko, V. К. (1989). Organzational Structure of Studying Process and its Development. Moscow: Pedagogy).

История механики с конца XVIII века до середины XX века (1972). Ашот Григорян и Б. Погребысский (ред.). М.: Наука (The History of Mechanics from the end of the XVIII century to the middle of the XX century. Ashot Grigorjan i B. Pogrebysskij (red.). M.: Science).

Платон (1899). Творения Платона. М.: Типо-лит. В. Рихтеръ. Т. 1. Сократические диалоги (Platon (1899). Works by Plato. A Collection of Studies. M.: Tipo-lit. V. Rihter. T. 1. Sokratic's dialogues).

Талызина, Н. Ф. (1975). Управление процессом усвоения знаний. М.: Издательство Московского Университета (Talyzina, N. F. (1975). Managing the Process of Knowledge Perception. Moscow: Publishing House of Moscow University).

Унт, И. Э. (1990). Индивидуализация и дифрреренциация обучения. М.: Педагогика (Unt, I. E. (1990). Individualization and Differentiation of Education. Moscow: Pedagogika). Шадриков, В. Д. (2014). Мысль и ее познание. М: Логос (Shadrikov, V. D. (2014). Thought and cognition. Moscow: Logos). 


\section{PEЗЮME}

Королёв Сергей. Зарождение и эволюция понятий механики с точки зрения улучшения методики ее преподавания.

Предлагается цикл новых комплексных подходов по улучшению методики преподавания механики. Ранее предложенные методы совершенствования методики еще находятся в употреблении, но их потенциал оказался почти исчерпанным в настоящее время. Имеет многообещающие перспективы данный комплексный подход, основанный на комплексном применении массива из нескольких базовых принципов, которые креативно и нестандартно комбинируются между собой во многих вариантах, в зависимости от конкретной ситуации. В минимальный массив базисов входят такие, как: использование опыта исторической эволючии базовых понятий механики; основные понятия по теории информации; применение компьютерной техники и учебных программных продуктов; создание множества математических моделей; комбинаторное сочетание базовых принципов с целью одновременного использования нескольких средств для решения конкретной проблемы. Их комплексное применение должно дать мультипликативный эффрект.

Ключевые слова: эволючия, механика, математическая модель явления, теория информации, диалектическое взаимодействие, комбинаторное сочетание, мультипликативный эффект.

\section{SUMMARY}

Koroliov Serhii. Origin and evolution of the concepts of mechanics in the light of improving the methodology of its teaching.

A series of new approaches are proposed to improve methodology of teaching mechanics by making extensive use of the experience of the historical evolution of basic concepts of mechanics and dialectically related concepts in information theory, computer technology, and mathematical models. Their comprehensive application should have a multiple effect. The fact of transferring knowledge and useful information from one generation to next generation is very important. Qualified transfer of knowledge and skills to students is the essence of pedagogy. This is what promotes civilization and makes Homo sapiens from just human being. The process of knowledge accumulation and translation must be as effective as possible for the success of a particular civilization. Scientist Plato claimed that the head of a person was not an empty pot that neededs to be filled with something, but a torch that needed to be lit. Effective "torch burning" needs to be complemented by knowledge and pedagogical practice. The philosopher of Ancient Greece, Protagoras was convinced that man was a measure of all things, that is, people reflected society. Over time, in some peoples the amount of knowledge reached a certain critical limit, according to the laws of dialectics, the quantity passed into quality, scientific facts generalized and separated from religion and the arts, all science and mechanics continued to evolve and became more complicated as new information was accumulated. For a long time mechanics was one whole with mathematics, astronomy, science.

The historical experience of development of mechanics and other sciences shows that the world around us can be regarded as a large "black box", which civilized humanity is gradually exploring. In the process of research, we create different mathematical models of the internal structure of this box, the models are simple at first, then complicated. These models are gradually approaching the true structure of the world as a result of the gradual increase in information from researchers that they subsequently process. An array of scientists of different ages and different peoples can be seen as a kind of analog computer, in which each researcher is a separate processor, all these biological processors working together on a complex and large- 
scale joint task. It is logical to assume that in teaching mechanics it will be useful to follow the historical sequence of development of concepts and ideas that arose in the process of development of ideas and evolution of mechanics. There is a good reason to believe that, when studying the concepts of mechanics in such a way, students will face a minimum of difficulties, i.e. there is a minimum of energy spent on learning and a multiplicative effect, if this were not the case, then the evolution of mechanics as a whole would go the other way.

Key words: evolution, mechanics, mathematical model of phenomenon, information theory, dialectical interaction, multiplicative effect.

UDC 372.881.111.1

Iryna Lobachova

SHEE "Donbas State Pedagogical University"

ORCID ID 0000-0001-7102-1915

DOI 10.24139/2312-5993/2019.05/120-131

\section{SOME ASPECTS OF FORMING STUDENT POSITIVE MOTIVATION TO LEARN FOREIGN LANGUAGES}

The article deals with the problem of forming student positive motivation to learn foreign languages. In the research the following ways of student motivation are proposed: encourage students to visualize their success; implement all the learning styles; use individual methods for every student; take the class beyond the classroom walls; tell students expectations and standards for learning; change in style and authority; give rewards to students; be firm with the class, etc. The ways for keeping students motivated while teaching a foreign language (let students know aims and objectives of learning; give learners what they need; present directions for learning; recognize work well done; personalize teaching; use team building activities; support practicality in actions, etc.) are offered. In further articles it is planned to consider innovative methods and means in teaching foreign languages in higher education institutions.

Key words: motivated student, encourage, foreign language learning activity, communicative situation, teaching methods, motivation, praise, learning style, teambuilding.

Introduction. Motivation in learning English plays a great role for mastering the foreign language material. For intellectual activity it is necessary to take into account that conscious external motivation (e.g. a sense of responsibility, duties in society, a motive of own well-being, mastering a foreign language for the future career; or a lack of desire to learn, realizing own failure due to a lack of language knowledge, etc.) and the internal one (e.g. availability and practicality of an educational material, topic variety, methods, techniques and means of informing) help to stimulate students' speech and mental activity, their thoughts and cause a desire to learn more and think in a foreign language. It creates positive conditions for learning a foreign language. It should be mentioned that without taking into account these factors, student speech activity becomes detached from real points of view, thoughts, interests, i.e. it loses a source that activates speech activity. 